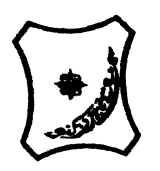

Bayero Journal of Pure and Applied Sciences, 12(1): 251 - 158

ISSN $2006-6996$

\title{
STUDIES OF Mn(II) COMPLEXES OF ACETYLTHIOPHENE AND ACETYL FURAN SCHIFF BASE DERIVATIVES
}

\author{
${ }^{1}$ Isyaku, S., * ${ }^{2}$ Aliyu, H. N., ${ }^{3}$ Ozoro, E.C. and ${ }^{1}$ Abubakar, T. \\ ${ }^{1}$ Department of Chemistry, Ahmadu Bello University Zaria \\ ${ }^{2}$ Department of pure and applied Chemistry, Bayero University Kano \\ ${ }^{3}$ Crescent International School, Kano \\ *Corresponding author: isyaku.sulaiman@yahoo.com
}

\section{ABSTRACT \\ Manganese(II) complexes of Schiff bases; 2-acetylthiophene-4-phenylthiosemi-}

carbazone (AT-PTSC) and 2-furylmethylketone-4-phenylthiosemi-carbazone (AF-PTSC)

derived from condensation of 2-acetylthiophene and 2-furylmethylketone (2-acetylfuran) each with 4-phenylthiosemicarbazide in (1:1 molar ratio) ethanol, have been synthesized. The Schiff bases and the Mn(II) complexes were characterized on the basis of melting point/decomposition temperature, solubility, magnetic susceptibility, infrared spectra, molar conductance measurements, elemental and gravimetric analyses. The Mn(II) complexes show moderate values of decomposition temperatures. The Schiff bases and the complexes were soluble in some common organic solvents. Infrared spectral data of the Schiff bases and their complexes, indicate coordination of the Schiff bases to the metal(II) ion via azomethine nitrogen. The effective magnetic moment of the Mn(II) complexes suggested an octahedral geometry. The molar conductance values of the complexes show that the complexes are electrolytes. The results of the elemental analysis of the ligands and their complexes are in good agreement with the calculated values, suggesting a 1:2 (metal-ligand) ratio. Antimicrobial screenings of the ligands and their complexes were conducted against against gram-positive (Staphylococcus aureus,) and two gram-negative (Salmonella typhi, and Escherichia coll) bacteria specie. Also three fungi mainly (Candida albicans, Mucus indicus and Aspergillus flavus) were tested. The results showed that both the ligands and the complexes are active against the bacteria and the fungi specie.

Keywords: Ligand, Schiff base, 4-phenylthiosemicarbazide, 2-acetylthiophene, 2acetylfuran molar conductivity, magnetic susceptibility, elemental analysis.

INTRODUCTION

Condensation between carbonyl compounds $(>\mathrm{C}=\mathrm{O})$ and a primary amine, produce a compound containing $>\mathrm{C}=\mathrm{NR}$ group connected to an aryl or alkyl group, known as a Schiff base (Pierre, 1987). Schiff base therefore is a weakly basic compound, obtained from aldehyde or ketone to form an imine or an anil or azomethine (Nic et al., 2006). Schiff base coordinates to active site of transition metals to form complexes through $\mathrm{N}, \mathrm{O}$ and $\mathrm{S}$ donor atoms, which make them important for their biological activity (Mishra et al., 2009). They have been used as analytical reagent, polymercoating, ink, pigment, fluorescent materials and catalytic reagent (Buhmann et al., 1998).

Thiosemicarbazones are class of sulphur (S) donor Schiff bases that are useful for transition metals due to their metal complexing ability (Abou-Melha et al., 2008). Thiosemicarbazone have significant activity against tumor, tuberculosis and leprosy (Ainstcough et al. 2007). Clinical and experimental studies on the effect of thiosemicarbazones revealed their activities against cancer (Marina et al. 2007). Drug synthesized from $\mathrm{N}$-methyl derivatives of isatin1- $\beta$-thiosemicarbazone (methisazone) is found to be active against small pox (Sau et al., 2003).

Thiophene-based compounds have widespread use in modern drug design, bio diagnostics, electronic, optoelectronic devices, conductive and electroluminescent polymers (Dore et al., 2004). Several reviews of various aspects of thiophene coordination and reactivity in transition metal complexes have been reported (Barbarella and Melucci, 2005). 2-butylthiophene has been employed as a raw material in the synthesis of anticancer agents and 2octylthiophene has been employed in the synthesis of anti-atherosclerotic agents (Richard et al., 2009). 
Special Conference Edition, November, 2019

The applications of thiophene and its derivatives as metal complexing agents and in the development of insecticides are well known, (Freeman et al., 1994).

Furan is used as a starting point to other special chemicals (Hoydonck et al., 2005). Furan derivatives of dihydronaphthalenes, are useful intermediates in the synthesis of other polycyclic aromatic compounds (Filatov et al., 2012). Many derivatives of furan have been found useful in condensation and coordination with other compounds and such compounds are biologically active against bacteria, fungi and virus. Schiff base derived from 3-aminodibenzofuran and 2furan carboxaldehyde was found to be active against tuberculosis and E. coli (Aurora et al., 2009).

Complexes of the Schiff base; 1,8-bis(thiophene2-carboxaldimine)-p-menthane $\left(\boldsymbol{L}^{\boldsymbol{1}}\right)$ and $1,8-$ bis(furan-2-carboxaldimine)- $p$-menthane $\quad\left(\boldsymbol{L}^{2}\right)$ have been very active against Gram positive bacteria; Bacillus subtitilus, Yersinia enterotica, Bacillus cereus Listeria monocytogenes and Micrococcus luteus, ( Ayla et al., 2016). The aim of this research is to synthesize, characterize and conduct antimicrobial studies on Schiff base derived from 2-acetylthiophene and 2acetylfuran with 4-phenylthiosemicarbazide.

\section{MATERIALS AND METHODS}

All the chemicals used in this work were of Analar Grade and were used without further purification. Glass wares used for the preparation were thoroughly washed with detergent, rinsed with distilled water and dried in an oven. The main chemicals; 4phenylthiosemicarbazide, 2-aceltylthiophene, and 2-acetylfuran (2-furylmethylketone) were all purchased from Sigma Aldrich U. K.

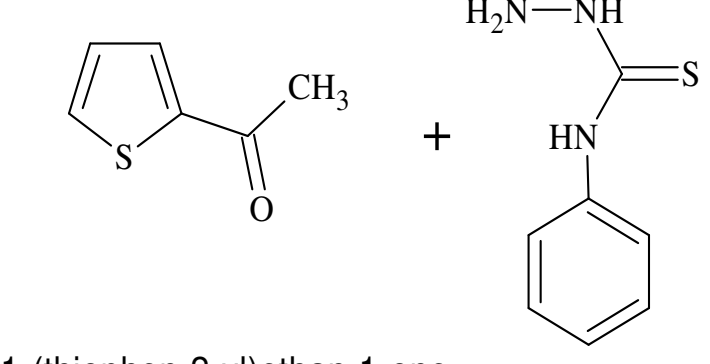

All weighing were carried out using Electrical Meter Balance $A B$ 54. Magnetic susceptibility measurements of the complexes were determined using Sherwood Scientific MSB MK1 Magnetic Susceptibility Balance. Melting point/Decomposition temperatures were determined using a digital WRS-IB Microprocessor Melting Point Apparatus. Infrared spectral analyses were recorded using Shimadzu FTIR-8400S Fourier Transform Infrared Spectrophotometer in the range $4500-250 \mathrm{~cm}^{-1}$. Molar conductivity measurements were carried out using George Kent model 5003 conductivity metre. Metal and Elemental Analysis of $\mathrm{C}, \mathrm{H}$ and $\mathrm{N}$ were carried out at Robertson Microlit Laboratories, New Jersey (U.S.A).

All the microbial isolates used in this were obtained from the Department of Medical Microbiology, Aminu Kano Teaching Hospital Kano, and identified at the Department of Microbiology. The antimicrobial screening was conducted in the Department of Microbiology, Bayero University Kano. Standard drugs; Ciprofloxacin for bacteria and Ketoconozole for fungi as reference standards were obtained from Department of Microbiology, Bayero University, Kano. Mueller Hinton agar and Potato dextrose were used as growth media for the microbes.

Preparation of Schiff Base (AT-PTSC)

To a hot solution of 4-phenylthiosemicarbazone $(1.67 \mathrm{~g}, 0.01 \mathrm{~mol})$ in $70 \mathrm{~cm}^{3}$ ethanol, a solution of 2-acetylthiophene $\left(0.01 \mathrm{~mol}, 1.08 \mathrm{~cm}^{3}\right)$, was added drop wise, followed by the addition of 3 drops of acetic acid. The mixture was refluxed with constant stirring for 3 hours. The solution was transferred into a refrigerator at $5^{\circ} \mathrm{C}$ for 24 hours. The precipitate obtained was filtered off, washed several times with ether and dried over $\mathrm{P}_{2} \mathrm{O}_{5}$ in a desiccator for three days (Chandra et al., 2009).

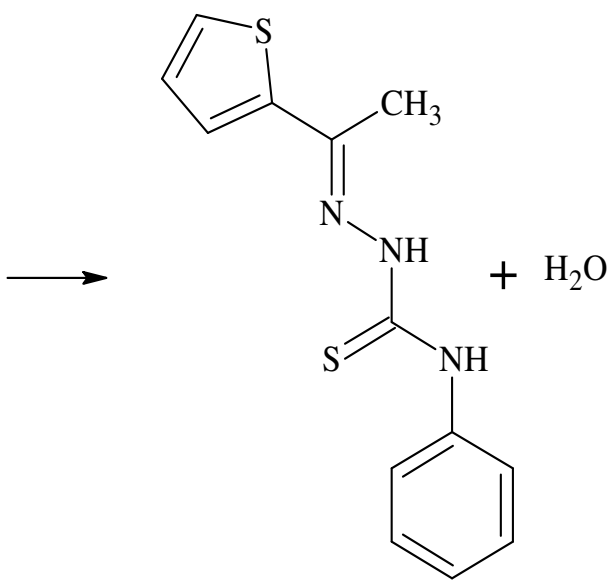

(2E)- $N$-phenyl-2-[1-(thiophen-2-yl)ethylidene]hydrazine-1-carbothioamide

Scheme 1: Preparation of AT-PTSC Schiff base 
Special Conference Edition, November, 2019 Preparation of Schiff Base (AF-PTSC)

The AF-PTSC Schiff base was synthesized using the same procedure for the synthesis of ATPTSC, only the reagent 2-furylmethylketone (2acetylfuran) was used instead of 2acetylthiophene.

Preparation of the Schiff base Manganese(II) complexes

$\mathrm{Mn}$ (II) complexes for the Schiff bases (AT-PTSC and AF-PTSC) derived from 2-acetylpyridine and 2-furylmethylketone with 4-phenyl thiosemicarbazide, were prepared by the addition of $0.002 \mathrm{~mol}$ of each of the Schiff bases in $20 \mathrm{~cm}^{3}$ ethanol to the solution containing $0.001 \mathrm{~mol}$ of each of the $\mathrm{Mn}$ (II) salts in $10 \mathrm{~cm}^{3}$ ethanol. Each of the mixture was then refluxed for 3 hours with stirring. On cooling, the precipitate obtained was filtered, washed with diethyl ether and dried over $\mathrm{P}_{2} \mathrm{O}_{5}$ in a desiccator for three days (Gehad et al., 2006).

\section{Infrared Measurements}

Shimadzu FTIR-8400S Fourier Transform Infrared Spectrophotometer in the range 250$4500 \mathrm{~cm}^{-1}$ was used. A small amount of powder sample (about $1-2 \%$ of $\mathrm{KBr}$ amount) was taken and mixed with $\mathrm{KBr}$ powder and then analyzed using infrared analyzer. The results obtained are shown in Table 4.

\section{Molar Conductance Measurement}

Molar conductivity measurements were carried out on $1 \times 10^{-3} \mathrm{moldm}^{-3}(0.001 \mathrm{M})$ solution of each of the metal complexes in Dimethyl Formamide (DMF) at $25^{\circ} \mathrm{C}$. The molar conductance is calculated using the equation, (Mohd, et al., 2013).

$$
\Lambda_{\mathrm{M}}=\frac{1000 \mathrm{~L}}{\mathrm{C}}
$$

The petri dishes were incubated at $37^{\circ} \mathrm{C}$ and the inhibition zone was measured after 24hours for bacterial strain and 48hours for fungal isolates and compared with standard drugs (Ciprofloxacin for bacteria and Ketoconozole for fungi) (Sheikh et al., 2004).
Where $\Lambda_{M}=$ molar conductance, $L=$ specific conductance and $\mathrm{C}=$ concentration of the complex. The results are presented in Table 5.

\section{Elemental Analysis}

The analysis was carried out using Perkin-Elmer CHN 2400 Elemental Analyzer based on the classical Pregl-Dumas method. About $20 \mathrm{mg}$ of each of the samples for analysis was encapsulated in an aluminium vial and inserted automatically into the combustion zone of the analyser using a single-sample auto injector. In the presence of excess oxygen and combustion reagents, the samples were combusted completely and reduced to the elemental gases $\mathrm{CO}_{2}, \mathrm{H}_{2} \mathrm{O}$ and $\mathrm{N}_{2}$. All the results were computed automatically and were given as percent weight of each element. The results are shown in Table 6.

\section{Antimicrobial Test}

The In vitro antimicrobial activity of the ligand (AP-PTSC) and its complexes were tested against Gram-positive (Staphylococcus aureus,) and two Gram-negative (Salmonella typhii, and Escherichia coli) pathogenic bacteria. Also three fungi mainly (Candida albicans, Mucus indicus and Aspergillus flavus) were used. Muller Hilton Agar media for bacteria while Potato Dextrose Agar (PDA) for fungi were used and were prepared in distilled water. The ligands and the complexes were dissolved separately in Dimethyl Sulphoxide (DMSO) to obtain three different concentrations $(15 \mu \mathrm{g} / \mathrm{ml}, 30 \mu \mathrm{g} / \mathrm{ml}$ and 60 $\mu \mathrm{g} / \mathrm{ml})$, which were used to check the antimicrobial activities by well diffusion method. The discs were saturated with the dissolved compounds in Dimethyl sulphoxide (DMSO) and then placed in petridishes containing the culture media.

\section{RESULTS}

The results of some physical properties, solubility, magnetic susceptibility, FTIR, molar conductance, elemental analysis and antimicrobial studies of the Schiff bases and the $\mathrm{Mn}$ (II) complexes are presented below:

Table 1: Some Physical Properties of (AT-PTSC and AF-PTSC) Schiff Bases with their Mn(II) Complexes

\begin{tabular}{llllll}
\hline Ligand /Complex, & Colour & $\begin{array}{l}\text { Melting } \\
\left({ }^{\circ} \mathrm{C}\right)\end{array}$ & $\begin{array}{l}\text { point } \\
\end{array}$ & $\begin{array}{l}\text { Decomposition } \\
\text { Temperature }\left({ }^{\circ} \mathrm{C}\right)\end{array}$ & $\begin{array}{l}\text { Percentage } \\
\text { Yield }\end{array}$ \\
\hline AT-PTSC & Light yellow & 176 & - & 85.2 \\
AF-PTSC & Light yellow & 178 & - & 85.1 \\
- -PTSC $\left.)_{2}\right]_{C 2}$ & Pale brown & - & 215 & 79.6 \\
{$\left[\mathrm{Mn}(\mathrm{AF}-\mathrm{PTSC})_{2}\right] \mathrm{Cl}_{2}$} & Brown & - & 220 & 75.8 \\
\hline
\end{tabular}

AT-PTSC and AF-PTSC = Schiff bases derived from 2-acetylthiophene and 2-acetylfuran with 4phenylthiosemicarbazide. [Mn(AT-PTSC $\left.)_{2}\right] \mathrm{Cl}_{2}$ and $\left[\mathrm{Mn}(\mathrm{AF}-\mathrm{PTSC})_{2}\right] \mathrm{Cl}_{2}=\mathrm{Mn}(\mathrm{II})$ complexes for the Schiff bases derived from 2-acetylthiophene and 2-acetylfuran with 4-phenylthiosemicarbazide. 


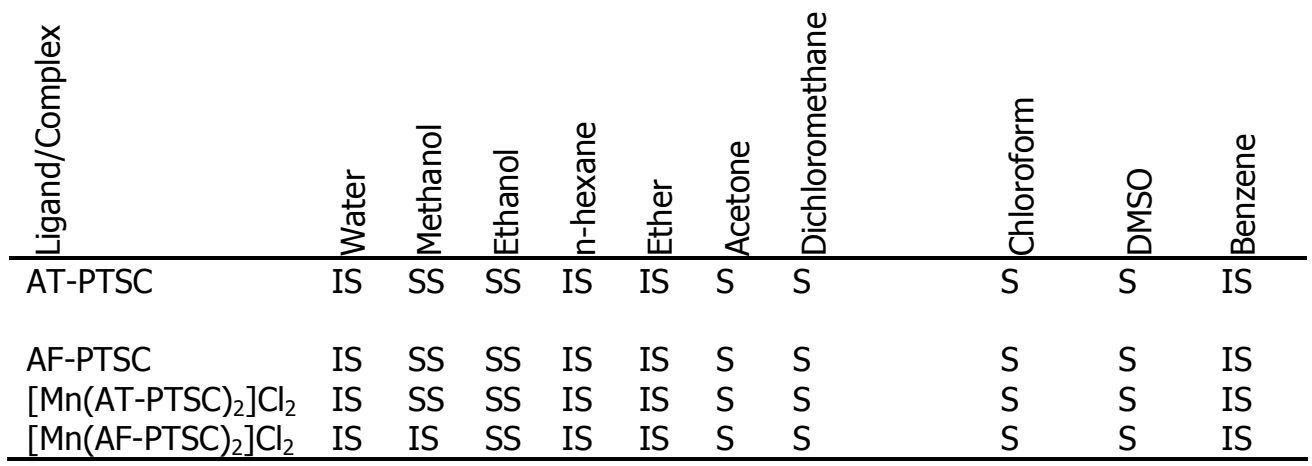

Key: IS $=>$ Insoluble, $S S=>$ Slightly Soluble, $\mathrm{S}=>$ Soluble

Table 3: Magnetic Susceptibility Values of AT-PTSC and AF-PTSC Mn(II) Complexes

\begin{tabular}{llcll}
\hline Complex & $\begin{array}{l}\text { Gram } \\
\text { susceptibility } \\
\left(\mathrm{X}_{\mathrm{q}}\right) 10^{-6}\end{array}$ & $\begin{array}{l}\text { Molar Magnetic } \\
\text { Susceptibility } \\
(\mathrm{Xm}) 10^{-3}\end{array}$ & $\begin{array}{l}\text { Magnetic } \\
\text { Moment } \mu_{\text {eff }} \\
(\mathrm{B} . \mathrm{M})\end{array}$ & Magnetic Property \\
\hline$\left[\mathrm{Mn}(\mathrm{AT}-\mathrm{PTSC})_{2}\right] \mathrm{Cl}_{2}$ & 24.0 & 0.16 & 6.0 & Paramagnetic \\
{$\left[\mathrm{Mn}(\mathrm{AF}-\mathrm{PTSC})_{2}\right] \mathrm{Cl}_{2}$} & 22.7 & 0.15 & 5.9 & Paramagnetic \\
\hline
\end{tabular}

Table 4: Infrared Spectra Data of AT-PTSC and AF-PTSC their Mn(II) Complexes

\begin{tabular}{llllll}
\hline Compounds & $\begin{array}{l}\mathrm{U}(\mathrm{C}=\mathrm{N}) \\
\left(\mathrm{cm}^{-1}\right)\end{array}$ & $\begin{array}{l}\mathrm{U}(\mathrm{N}-\mathrm{H}) \\
\left(\mathrm{cm}^{-1}\right)\end{array}$ & $\begin{array}{l}\mathrm{U}(\mathrm{C}=\mathrm{S}) \\
\left(\mathrm{cm}^{-1}\right)\end{array}$ & $\begin{array}{l}\mathrm{U}(\mathrm{M}-\mathrm{S})_{\text {Thio }} \\
\left(\mathrm{cm}^{-1}\right)\end{array}$ & $\begin{array}{l}\mathrm{U}(\mathrm{M}-\mathrm{S}) \\
\left(\mathrm{cm}^{-1}\right)\end{array}$ \\
\hline AT-PTSC & 1648 & 3289 & 852 & - & - \\
AF-PTSC & 1522 & 3281 & 750 & - & - \\
{$\left[\right.$ Mn $\left.(\text { AT-PTSC })_{2}\right] \mathrm{Cl}_{2}$} & 1633 & 3280 & 849 & 529 & 405 \\
{$\left[\right.$ Mn $\left.(\text { AF-PTSC })_{2}\right] \mathrm{Cl}_{2}$} & 1510 & 3287 & 753 & 548 & 403 \\
\hline
\end{tabular}

Table 5: Molar Conductance Measurement for AT-PTSC and AF-PTSC Mn(II) Complexes

\begin{tabular}{lllll}
\hline Compound & $\mathrm{FW} \mathrm{gmol}^{-1}$ & $\begin{array}{l}\text { Conc. } \\
\left(\text { Moldm }^{-3}\right) \\
\times 10^{-3}\end{array}$ & $\begin{array}{l}\text { Specific } \\
\text { Conductance } \\
\times 10^{-4} \mathrm{~S}^{-1}\end{array}$ & $\begin{array}{c}\text { Molar } \\
\text { Conductance } \\
\Omega^{-1} \mathrm{~cm}^{2} \mathrm{~mol}^{-1}\end{array}$ \\
\hline$\left[\mathrm{Mn}(\mathrm{AT}-\mathrm{PTSC})_{2}\right] \mathrm{Cl}_{2}$ & 676.63 & 2.36 & 2.98 & 126.02 \\
{$\left[\mathrm{Mn}(\mathrm{AF}-\mathrm{PTSC})_{2}\right] \mathrm{Cl}_{2}$} & 644.50 & 1.86 & 2.30 & 123.53 \\
\hline
\end{tabular}


Special Conference Edition, November, 2019

Table 6: Elemental Analysis of AT-PTSC and AF-PTSC with their Mn(II) Complexes

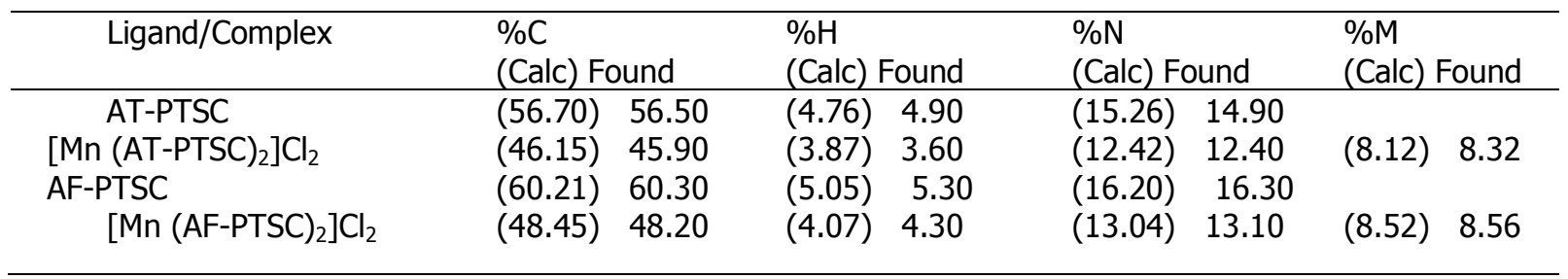

Table 7: Antibacterial Activity of AT-PTSC and AF-PTSC with their Mn(II) Complexes

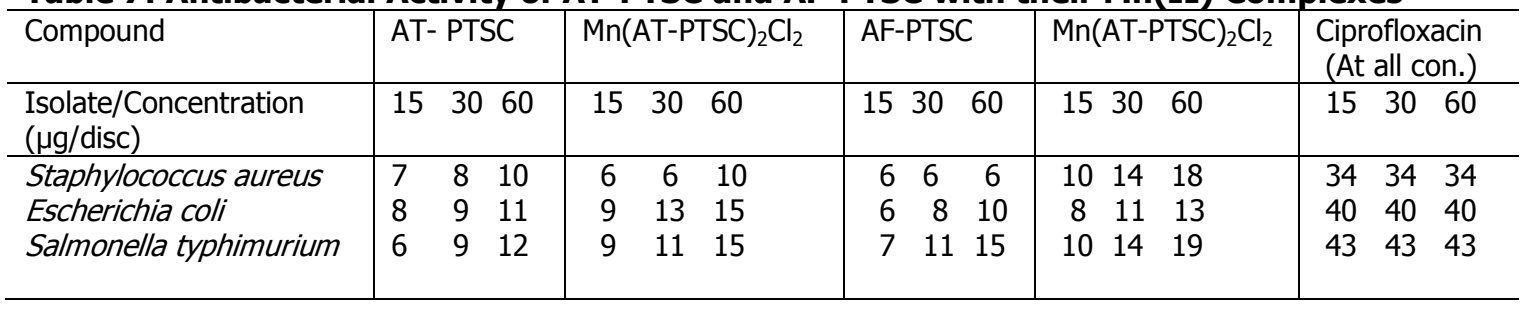

Table 8: Zone of Inhibition ( $\mathrm{mm}$ ) for Antifungal of AT-PTSC and AF-PTSC with their Mn(II) Complexes

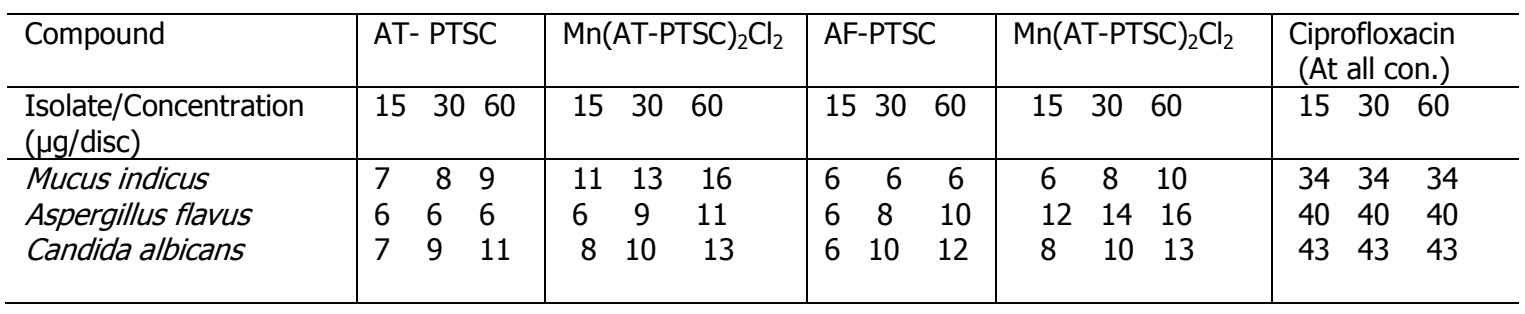

\section{DISCUSSION}

Reaction between 2-acetythiophene and 2acetylfuran (2-furylmethylketone) each with 4phenylthiosemicarbazide in (1:1 molar ratio) in ethanol produced a Schiff base; 2acetylthiophene-4-phenylthiosemicarbazone and 2-acetylfuran-4-phenylthiosemicarbazone (ATPTSC and AF-PTSC). Mn(II) complexes were synthesized from these Schiff bases in (2:1 molar ratio) in ethanol. The Schiff bases ATPTSC and AF-PTSC together with [Mn(ATPTSC $\left.)_{2}\right] \mathrm{Cl}_{2}$ and $\left[\mathrm{Mn}(\mathrm{AF}-\mathrm{PTSC})_{2}\right] \mathrm{Cl}_{2}$ complexes were subjected to spectroscopic analyses based on melting point/decomposition temperature, solubility, magnetic susceptibility, infrared (IR) spectra, molar conductance measurements, elemental and gravimetric analysis.

\section{Physico-Chemical Properties of the Schiff Base and its Metal(II) Complexes}

Both the AT-PTSC and AF-PTSC Schiff bases are light yellow powders with a yield of $85.2 \%$ and $85.1 \%$, a melting point of $176^{\circ} \mathrm{C}$ and $178^{\circ} \mathrm{C}$.
The complexes $\left[\mathrm{Mn}(\mathrm{AT}-\mathrm{PTSC})_{2}\right] \mathrm{Cl}_{2}$ and $[\mathrm{Mn}(\mathrm{AF}-$ PTSC $\left.)_{2}\right]_{C l}$ are pale brown and brown, a decomposition temperature of $215^{\circ} \mathrm{C}$ and $220^{\circ} \mathrm{C}$ and a yield of $79.6 \%$ and $75.8 \%$ (Table 1 ). The variation in colour of the Schiff bases with their corresponding complexes indicates coordination of each of the Schiff base with the $\mathrm{Mn}$ (II) ion.

The colour of the compounds is attributed to ' $d$ d' orbital transition of electron between one energy level to another, by their magnitude of splitting, which in turn depends on the geometry of the complex, the nature of the ligand and charge transfer (Rodgers, 1994). The decomposition temperatures of the complexes are relatively high, indicating good thermal stability of the complexes.

Both the Schiff bases and their $\mathrm{Mn}$ (II) complexes are soluble in acetone, dichloromethane, chloroform and DMSO but slightly soluble in methanol and ethanol, except $\left[\mathrm{Mn}(\mathrm{AF}-\mathrm{PTSC})_{2}\right] \mathrm{Cl}_{2}$ which is insoluble in methanol, (Tables 2). 
Special Conference Edition, November, 2019

The solubility of the Schiff bases and their $\mathrm{Mn}$ (II) complexes in the common solvents indicated their low polarity which can be used to determine the suitable solvents that could be utilized for subsequent spectroscopic measurements (Jones and Fleming, 2010).

The magnetic susceptibility as presented in (Tables 3) are 6.0BM and 5.9BM for [Mn(ATPTSC $\left.)_{2}\right] \mathrm{Cl}_{2}$ and $\left[\mathrm{Mn}(\mathrm{AF}-\mathrm{PTSC})_{2}\right] \mathrm{Cl}_{2}$, indicating paramagnetic high spin octahedral geometry (Gehad et al., 2006).

The Schiff bases show broad band spectra at $1648 \mathrm{~cm}^{-1}$ and $1522 \mathrm{~cm}^{-1}$, that are attributable to $\mathrm{U}(\mathrm{C}=\mathrm{N})$ stretching vibration, which is shifted downward in the spectra of the complexes at range of $1633-1510 \mathrm{~cm}^{-1}$. This indicates coordination of the Schiff bases to each of the $\mathrm{Mn}$ (II) ion via azomethine nitrogen. The spectra of the Schiff bases at $3289 \mathrm{~cm}^{-1}$ and $3281 \mathrm{~cm}^{-1}$ assignable to $\mathrm{u}(\mathrm{N}-\mathrm{H})$ stretching vibration shifted downward and upward in the spectra of the complexes at $3280 \mathrm{~cm}^{-1}$ and $3287 \mathrm{~cm}^{-1}$, which resupports coordination of the Schiff bases to the $\mathrm{Mn}$ (II) ion. The band spectra of the complexes at the region of $529-548 \mathrm{~cm}^{-1}$ and $403-405 \mathrm{~cm}^{-1}$ are assignable to $\mathrm{U}(\mathrm{M}-\mathrm{N})$ and $\mathrm{U}(\mathrm{M}-$ $S)$ respectively, which is another indication for the coordination of the Schiff base to the metal(II) ion, (Awadelkareem et al., 2012), (Tables 4).

The molar conductivities of [Mn(AT-PTSC) $\left.)_{2}\right] \mathrm{Cl}_{2}$ and $\left[\mathrm{Mn}(\mathrm{AF}-\mathrm{PTSC})_{2}\right] \mathrm{Cl}_{2}$ were carried out in DMF and their $10^{-3} \mathrm{M}$ solutions are $126.02 \Omega^{-1} \mathrm{~cm}^{2} \mathrm{~mol}^{-1}$ and $123.53 \Omega^{-1} \mathrm{~cm}^{2} \mathrm{~mol}^{-1}$ as shown in (Table 5 ). These values indicate electrolytic nature of the complexes, (Gehad et al., 2006; Mohd, et al., 2013).

The results of the elemental analysis $(\mathrm{C}, \mathrm{H}$ and $\mathrm{N})$ for the Schiff bases and their respective<smiles>CC1=NN=C(NC(=S)Nc2ccccc2)SN1Sc1nnc(C)c2sccc12</smiles>

Where $\mathrm{M}=\mathrm{Mn}$,
Mn(II) complexes are as presented in Table 6. The values are in agreement with the proposed formulas of the ligands, and their corresponding $\mathrm{Mn}$ (II) complexes, suggesting 2:1(ligand-metal ratio).

Antimicrobial test of the AT-PTSC and AF-PTSC Schiff bases and their $\mathrm{Mn}$ (II) complexes were carried out against three bacteria isolates; Gram-positive (Staphylococcus aureus,), Gramnegative (Salmonella typhii, and Escherichia coll) and three fungi (Candida albicans, Mucus indicus and Aspergillus flavus). Concentrations of 15, 30 and $60(\mu \mathrm{g} / \mathrm{disc})$ were used, standard drugs ciproflaxacin and ketoconozole for bacteria and fungi, were served as controls, (Tables 7-8). The results of the tests indicate moderate antimicrobial activity against the tested microorganisms when compared with the standards, and this activity increases by increasing concentration. Also the metal complexes show higher activities than free ligand, except in the case of [Mn(AT-PTSC $\left.)_{2}\right] \mathrm{Cl}_{2}$ where its activity against Staphylococcus aureus, is lower than that of the Schiff base. However, the activities of both the ligand and the complexes are less than that of the standard drugs used. The activities of the compounds can be explained on the basis of chelation theory, which states that; the chelation tends to make the complex acts as a more powerful and potent bactericidal or bacteriostatic agent than the ligand (Sengupta et al., 1998).

From the results of analysis of the complexes and the available literature data, the following general molecular structures for [Mn(ATPTSC $\left.)_{2}\right] \mathrm{Cl}_{2}$ and $\left[\mathrm{Mn}(\mathrm{AF}-\mathrm{PTSC})_{2}\right] \mathrm{Cl}_{2}$ are proposed:

Figure 1: Proposed Structure of 2-acetythiophene-4-phenylthiosemicarbazone (AT-PTSC) Metal(II) Complexes. 


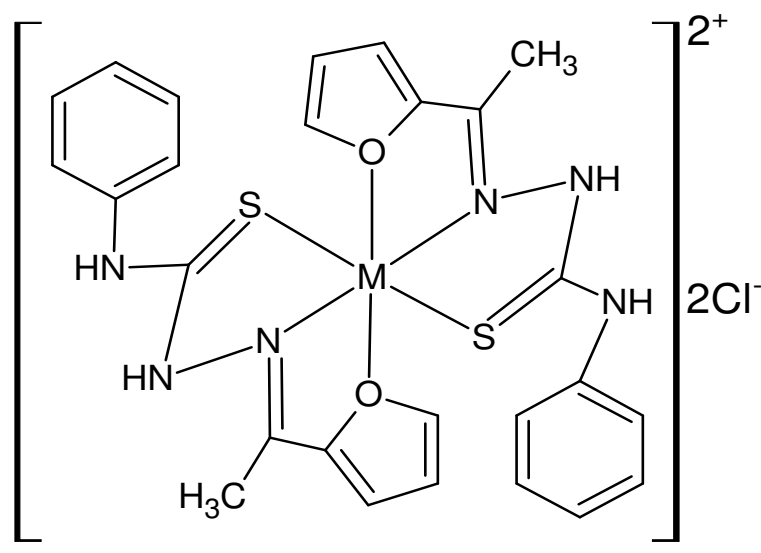

Where $M=M n$.

Figure 2: Proposed Structure of 2-acetylfuran-4-phenylthiosemicarbazone (AF-PTSC) Metal(II) Complexes.

\section{CONCLUSION}

Schiff bases acetylfuran-4-phenylthiosemicarbazone PTSC) together with their $\mathrm{Mn}$ (II) complexes were successfully synthesized and characterized. The decomposition temperature indicates the good stability of the complexes. The IR values assignable to $\mathrm{u}(\mathrm{N}-\mathrm{H})$ and $\mathrm{U}(\mathrm{C}=\mathrm{N})$ stretching vibrations show coordination of the ligand to the metal ion via azomethine nitrogen. Molar

\section{REFERENCES}

Abou-melha, K. S. and Faruk, H. (2008). Bimetallic Complexes of Schiff base bis[4-hydroxycuomarin-3-yl]-1N-5Nthiocarbohydrazone as a potentially dibas ic pentadentate ligand. Synthesis, spectral and antimicrobial properties. Journal of the Iranian Chemical Society, (1):122-134.

Ainscough, E. W., Brodie, A. M., Ranford, J. A. and Waters, J. M. (2007). Reaction of anionic oxygen donors which the antitum or copper(II)-pyridine-2-carbodehyde thiosemicarbazone $(\mathrm{HL})$ system and the $\mathrm{c}$ rystal structure of $\left[\left\{\mathrm{Cu}(\mathrm{HL})\left(\mathrm{H}_{2} \mathrm{PO}_{4}\right)\right\} 2\right]\left[\mathrm{H}_{2}\right.$ $\left.\mathrm{PO}_{4}\right] 2.2 \mathrm{H}_{3} \mathrm{PO}_{4} \cdot 2 \mathrm{H}_{2} \mathrm{O}$. Journal of Chemical Society 37:1251-1255.

Aurora, R., Stelian, F., Theodor, C. and Nicolae, S . (2009). Synthesis, characterization, and antibacterial activity of some transition metals with the Schiff base N(2-furanylmethylene)-3 amino dibenzofuran. Turk J Chem, 33: 775783.

Awadelkareem, A. A., Hassan, N., Cenk, A. Volker, H., Ulrich, R.,Karl-Herbert, S. conductance values range from $126.02 \Omega$ ${ }^{1} \mathrm{~cm}^{2} \mathrm{~mol}^{-1}$ and $123.53 \Omega^{-1} \mathrm{~cm}^{2} \mathrm{~mol}^{-1}$, showing that the solutions of the complexes are electrolytes. The values of the magnetic susceptibility of the complexes indicated an octahedral geometry. The elemental analysis values indicates 2:1(ligand-metal ratio). The antimicrobial test shows that both the ligand and the complexes have good activity against the isolates used. Finally the structures of the complexes have been proposed.

and Michael, V. (2012). Organoplatinum( II) Complexes with 2-Acetylthiophene Thiosemicarbazone: Synthesis, Characterization, Crystal Structures and inVitro Antitumor Activity. Organometallics, 31: 2256-2262.

Ayla, B.G., Iffet, O., Hamit, A., Saliha, A., and Naslihan, O. (2016). Biologically active Schiff bases containing thiophene/furan ring and their copper(II) complexes: Synthesis, spectral, nonlinear optical and density functional studies. journal of molecular structure 1120:259-266.

Barbarella, G. M. and Melucci, G. S. (2005). Shaping Thiophene Oligomers into Fluorescent Nanobeads Forming TwoDimensionally Patterned Assemblies by the Capillary Effect Macromolecules, 38 (24): 10050-10054

Buhlmann, P. Pretsch, E. and Bakker, E. (1998). Carrier-based ion-selected electrodes and bulk optodes.2. Ionophores for potentiometric and opticcal sensors..Chemical Rev., 98 (4):15931687. 
Special Conference Edition, November, 2019

Chandra, S., Parmar, S. and Kumar, Y. (2009): Synthesis, Spectroscopic and Antimicrobial Studies on Bivalent Zinc and Mercury Complexes of 2- Formyl pyridine thiosemicarbazone. Bioinorganic Chemical Application,10:1155-1161.

Dore, K., Dubus, S., Ho, H. A., Le'vesque, I., Brunette, M., Corbeil,G., Boissinot, M., Boivin, G., Bergeron, M. G., Boudreau, D. and Leclerc, M. (2004). Fluorescent polymeric transducer for the rapid, simple and specific detection of nucleic acids at the zeptomole level. J. Am. Chem. Soc., 126(13):4240-4244.

Filatov, M. A., Baluschev, S., Ilieva, I. Z., Enkelmann, V., Miteva, T., Landfester, K.,

Aleshchenkov, S. E. and Cheprakov, A.V. (2012). Tetraaryltetraanthra[2,3]porphyri s: Synthesis, Structure, and Optical Properties. J. Org. Chem., 77(24):111113.

Freeman, F., Lee, M. Y., Lue, H., Wang, X. and Rodriguez, E. (1994). Thiophene, , derivatives and Applications.J. Org. Chem., 50: 369.

Gehad, G. M., Mohamed, M.O., Ahmed, M. H. (2006): Metal Complexes of Schiff Bases: Preparation, Characterization, and Biological Activity.Turk J. Chem., 30: 361-382.

Hoydonckx, H. E., Van Rhijn, W. M., Van Rhijn, W., De Vos, D. E. and Jacobs, P. A.. (2005). Furfural and Derivative. Ullmann's EncyclopediaofIndustrial Chemistry, Wiley andsons Weinheim, pp 12-19.

Jones, M. and Fleming, S. A. (2010). Organic Chemistry $\left(4^{\text {th }}\right.$ ed) USA: Nortown company Inc., pp14-16.

Marina, C., Mirta, R., Ivica, D., Gerald, G. and Boris, K. (2007). Oxovanadium(V) coplexes of salicylaldehyde and 3-methox ysalicylaldehyde 4 phenylthiosemicarbazo $\mathrm{n}$ : Formation of two new thiazoline compounds. Journal of Croatica Chemical society, 80(3): 583-590.

Mishra, A. P., Mishra, R. K. and Shrivastava, S. P. (2009). Structural and antimicrobial studies of Coordination compounds of
V(II), Co(II) with some Schiff bases involving 2-amino-4-

chlorophenol. Journal of the Serbian Che mical Society, 74:523-535.

Mohd, A. K., Ruchi A. and Shamim A. (2013). Synthesis, structural characterization and biological activity of transitionmetal complexes of schiff base ligand-furan derivatives. Journal of Chemical and Pharmaceutical Research, 5(12):12891296

Nic, M., Jirat, J. and Kosata, B. (2006). Schiff base. IUPAC Compendium of Chemical Terminology.

DOI:10.1351/goldbook.S05498. ISBN 096785 9-8.

Richard, D. M., Osaka, I., Zhang, R., Sauve, G., Smilgies, D.M. and Kowalewski, T., (2009). High-lamellar ordering and amorphous-like n-network in short-chain thiazolothiazole- thiophene copolymers lead to high mobilities, Journal of American Chemical Society 131(7): 25212529.

Rodgers, G. E. (1994). Introduction to Coordination, Solid State and Descriptive Inorganic Chemistry. McGraw-Hill: New York, p. 4.

Sau, D.K., Butcher, R.J., Chaudhuri, S. and Saha, N. (2003). Spectroscopic, structural and ssantibacterial properties of copper(II) complexes with bio-relevant 5- methyl3-formylpyrazoneN(4)-benzyl-N(4)methylthiosemicarbazone. Journal of Molecular Cell biochemistry, 25:21-29.

Sengupta, S. K., Pandey, O. P., Srivastava, B. K. and Sharma, V. K. (1998). Synthesis, Structural and Biochemical aspects of Titanocene and Zirconocene Chelates of acetylferrocenyl thiosemicarbazones. Tra nsition Metal Chemistry,23(4):349-353.

Sheikh, C., Hossain, M.S., Easmin, M.S., Islam, M.S. and Rashid, M. (2004). Evaluation of in vitro antimicrobial and in vivo cytotoxic properties of some novel titaniumbased coordination complexes. Biological and Pharmaceautical Bulletin, 27(5):2105-2108. 